\title{
José María Arguedas aquém da literatura
}

\author{
MARCOS PIASON NATALI
}

$\mathrm{N}$

Ão É INCOMUM pensarmos a historiografia como uma prática abstrata e neutra, um receptáculo maleável que pode ser preenchido por conteúdo de diversas naturezas e origens. Assim, se uma determinada sociedade não escreveu sua história, imaginamos que o exercício na verdade não seria demasiadamente difícil. Bastaria juntarmos dados - a matéria da pesquisa historiográfica: documentos e testemunhos - para, a partir deles, construirmos um relato histórico. E essa narrativa seria, formal e conceitualmente, em sua estrutura e suas normas disciplinares, semelhante a tantas outras já elaboradas, com a mesma temporalidade vazia, homogênea, desencantada e linear, independentemente da experiência temporal na sociedade cuja história estivesse sendo contada ${ }^{1}$.

O que ocorre com o termo literatura não é significativamente diferente. Da mesma forma em que pensamos que cada sociedade tem a sua história, que por sua vez é a variante de uma idéia abstrata, cada sociedade teria, também, sua literatura. Assim, não estranharíamos encontrar nas prateleiras de uma biblioteca livros com títulos como História da China, História da Inglaterra ou História dos incas, ou então outros intitulados Literatura chinesa, Literatura inglesa ou Literatura pré-hispânica, mesmo se descobríssemos que os signos "história" e "literatura" não se desestabilizam na passagem de um livro a outro. No entanto, no caso da historiografia podemos, quando pressionados, imaginar algo próximo a uma definição do termo: conseguimos identificar as normas específicas que regem a prática e descrever sua construção particular não só do tempo como do espaço, da subjetividade humana e da relação entre o presente e o passado, delineando assim seus contornos conceituais e sua especificidade epistemológica e identificando o que na historiografia representou uma novidade. A elaboração de uma definição de literatura é um exercício mais trabalhoso. Não é raro, afinal, que as reflexões sobre a literatura enfatizem justamente sua suposta falta de contornos e sua ilimitada capacidade de assimilação, em alguns casos chegando a negar que a literatura seja historicamente específica.

A situação não é assaz diferente na maioria das histórias literárias hispanoamericanas de meados do século XX. O reconhecimento da especificidade e estranheza da prática literária é raro nos relatos da expansão da literatura pelos países do continente, inclusive quando o foco da análise é a relação entre a literatura e outras práticas culturais. A mais influente teoria elaborada pela crítica literária para descrever as relações culturais da região no período - a idéia de trans- 
culturação literária, edificada na obra do crítico uruguaio Ángel Rama a partir de formulação inicial do cubano Fernando Ortiz - não foge à regra e também destaca a capacidade elástica que a literatura teria de incorporar diferentes línguas, visões de mundo e objetos. A transculturação narrativa - o processo que Rama identifica em autores como o peruano José María Arguedas, o mexicano Juan Rulfo, o colombiano Gabriel García Márquez e o brasileiro João Guimarães Rosa, todos "criadores literários que constroem as pontes indispensáveis para resgatar as culturas regionais" - seria a "busca de soluções artísticas que não sejam contraditórias com a herança que devem transmitir" 2 . Assim, Rama afirmará que "a contribuição original dos transculturadores consiste na unificação" do texto literário, para concluir que a transculturação "restaura a visão regional" bulário eufórico de resgates, restaurações e soluções, note-se, é convocado para descrever um processo que não parece ser outra coisa senão a tradução da cultura local à literatura.

Arguedas seria para Rama um paradigma dessas "soluções transculturais" e, após as formulações pioneiras do crítico, as leituras da obra do escritor peruano inclinaram-se a encontrar nela justamente um exemplo da inserção bem-sucedida do local no sistema global ${ }^{4}$. E é verdade que boa parte da obra de Arguedas é de fato exatamente isto: a tentativa de inscrever o mundo andino em que o autor crescera, com sua língua, sua cultura e sua religiosidade, na forma da narrativa literária moderna. No período em torno ao romance Los ríos profundos (1958), a etapa que serviria de base para as teorizações transculturadoras, vários textos de Arguedas de fato não estavam distantes de formulações em que o limite da diferença cultural é a identidade nacional ou regional. Sua obra parecia confluir para uma posição como a de Fernando Ortiz, que certa vez, após descartar o que chamara de culturas particularistas de Cuba, recomendou que "Trabalhemos juntos pela cultura própria no seio da universal" ". Nesses casos, o discurso identitário nacionalista ou regionalista é uma forma de participar no banquete das nações, com a inscrição na cultura dominante - freqüentemente chamada de universal, como no texto de Ortiz - mantendo-se como meta final.

O conto "La agonía de Rasu-Ñiti”, publicado por Arguedas em 1962, é exemplar nesse sentido. O relato reconstrói uma dança ritual, a tradicional dança das tesouras, no dia em que ela serve de ritual preparatório para a morte de RasuNiti, o dançarino (dansak') de uma comunidade indígena andina. A morte de fato ocorrerá em meio à dança, embora a cerimônia agônica se converta em uma espécie de celebração, com a continuação da dança pelo discípulo de Rasu-Ñiti revelando a continuidade de sua existência ${ }^{6}$.

Uma leitura do conto através da chave da transculturação não estaria equivocada, já que o texto é, essencialmente, a transformação de uma cerimônia religiosa em literatura. $\mathrm{O}$ que Rama escrevera sobre a transculturação de modo geral - que nela há uma busca da reconstrução daquilo que ele chama de "cosmovisão cultural" ${ }^{7}$ - certamente vale para o conto. Para o crítico uruguaio, essas obras 
instalam-se na intra-realidade latino-americana, cumprem a ingente tarefa de abarcar elementos contrários cujas energias buscam canalizar harmonicamente, resgatam o passado e apostam em um futuro que acelere a expansão da nova cultura, autêntica e integradora ${ }^{8}$.

Esta suposta harmonia e a conciliação de contrários são, na verdade, a absorção da heterogeneidade pela voz soberana da modernidade, através da fórmula que une dados locais à forma européia. O conceito de conto literário fornece uma categoria para a classificação e recepção do texto, enquanto seu alto grau de legibilidade é garantido pelas traduções lingüísticas e conceituais em notas de rodapé e entre parênteses no próprio corpo do texto. A voz antropológica apresenta e domestica a ameaça da diferença, como no seguinte esclarecimento do narrador sobre os dançarinos:

Bailan solos o en competencia. Las proezas que realizan y el hervor de su sangre durante las figuras de la danza dependen de quién está asentado en su cabeza y su corazón, mientras él baila o levanta y lanza barretas con los dientes, se atraviesa las carnes con leznas o camina en el aire por una cuerda tendida desde la cima de un árbol a la torre del pueblo.

"El genio de un dansak' depende de quién vive en él", explicará ainda este trecho que poderia estar em um estudo etnográfico.

Os rastros de uma possível alteridade andina na literatura arguediana desse período não extrapolam os limites da literatura moderna e as convenções do realismo maravilhoso. No entanto, mesmo antes da radicalização que seria $E l$ zorro de arriba y el zorro de abajo, é possível encontrar em Arguedas indícios de uma versão menos triunfalista e eufórica do encontro cultural. Já em 1950, o autor se perguntava em que língua devia escrever:

¿En castellano? ¿Después de haberlo aprendido, amado y vivido a través del dulce y palpitante quechua? Fue aquel un trance al parecer insoluble. Escribí el primer relato en el castellano más correcto y "literario" de que podía disponer. [...] Pero yo detestaba cada vez más aquellas páginas. [...] Bajo un falso lenguaje se mostraba un mundo como inventado, $[\ldots]$ un mundo "literario", en que la palabra ha consumido a la obra ${ }^{10}$.

Note-se que o problema, para Arguedas, é conceitual; seu desconforto é provocado pela literariedade e a ficcionalidade daquilo que é escrito em espanhol.

Também no romance Los ríos profundos está presente, em mais de um trecho, a consciência da tensão do processo de produção lingüística. Em um deles, o narrador Ernesto tenta escrever, em nome de um amigo, uma carta romântica, até que "un descontento repentino, una especie de aguda vergüenza", faz com que ele interrompa a redação da carta. $\mathrm{O}$ adolescente então imagina, como destinatárias da carta, meninas indígenas de seu povoado, perguntando-se: “¿Y si ellas pudieran leer? ¿Si a ellas pudiera yo escribirles?” Imaginar a mudança do leitor empírico é suficiente para levar Ernesto a passar do espanhol ao quéchua e 
a escrever uma nova carta, que ele compara a um canto e o romance reproduz, primeiro em quéchua, depois em espanhol, em algumas das linhas mais poéticas de todo o livro. A necessidade da passagem a outro idioma, bem como a constatação soturna de que "Escribir para ellas era inútil, inservible"11, assinala que estamos distantes da simples recuperação de uma cultura através de sua inserção em uma sociedade alheia, como gostaria Rama. A obrigatoriedade da tradução, aqui ou em textos como "La agonía de Rasu-Ñiti”, sublinha os limites impostos pelos leitores empíricos de Arguedas, algo que ele reconhecia e lamentava, dizendo poder apenas sonhar com seu público ideal - leitores quéchuafalantes e alfabetizados, um grupo restrito no Peru dos anos de 1950 e 1960. A tragédia do adolescente Ernesto, como a de Arguedas em suas próprias produções verbais, é reconhecer que a conciliação já não é possível.

Tensões semelhantes podem ser encontradas em textos de outros escritores identificados como exemplos de um hibridismo cultural exitoso. No romance Hombres de maiz, do guatemalteco Miguel Ángel Asturias, um aldeão se escandaliza ao chegar à cidade e ver em uma oficina a produção de imagens de santos, lembrando-se de como os escultores tradicionais se isolavam na selva para criar imagens religiosas. A narrativa explica:

Es que no debía ser permitido que las imágenes se trabajaran como si fueran maniquíes o muebles. [...] Quizás por el antecedente, no le gustaba ver tras la mampara de vidrio que daba a la reja de un balcón, a los que hacían los santos, fumando, escupiendo, silbando, y a los santos que los rodeaban, sin ropa ${ }^{12}$.

Em casos como este narrado pelo romance de Asturias, o encontro com um outro modo de produção leva a uma crise, pois a afirmação da diferença da natureza do objeto religioso choca com sua produção e circulação como mercadoria. (Em seguida, uma imagem será devolvida à fábrica, com a alegação de que lhe falta "alma”.) Mas a crise é incorporada ao nível temático da narrativa sem que o estatuto da obra literária seja comprometido. Se a colisão com a produção moderna provoca uma crise nos personagens, a mesma tensão fora das páginas do livro não impede a produção de romances como Los ríos profundos e Hombres de maíz.

Na obra de Arguedas composta após Los ríos profundos ocorre uma crise ainda mais profunda, que o levará a se aproximar de práticas discursivas nãoeuropéias e a escrever mais em quéchua, com a crescente insatisfação com as soluções do hibridismo cultural levando-o a um questionamento das normas do discurso literário. Sua obra final, o livro El zorro de arriba y el zorro de abajo, inclui, conforme fora especificado em instruções deixadas pelo escritor antes de seu suicídio, diálogos entre seres mitológicos incas, um relato sobre os trabalhadores da indústria de farinha de peixe no povoado de Chimbote, um discurso feito por Arguedas ao receber o prêmio "Inca Garcilaso de la Vega" e cartas escritas a colegas e amigos com despedidas e instruções para seu enterro, tudo entrecortado por diários do escritor. A presença dos seres mitológicos - as raposas, ou “zorros", do título - faz do livro uma continuação do manuscrito quéchua 
Dioses y hombres de Huarochirí, uma compilação de narrativas orais registradas no século XVI e traduzidas ao espanhol por Arguedas em 1966. O diálogo entre as raposas, interrompido no manuscrito original, cujo objetivo era apenas a identificação de idolatria, é retomado na obra de Arguedas, surgindo em trechos cruciais do romance. Com a aparição das raposas, o relato torna-se parte de uma narrativa antiga e não-literária cuja origem antecede a chegada da literatura aos Andes. O relato de Arguedas será, como o manuscrito de Huarochirí, um texto inacabado e fragmentário, interrompido por uma tragédia ${ }^{13}$.

Se a estrutura fragmentária e a pluralidade de gêneros e registros lingüísticos certamente não são estranhas à tradição literária européia do século XX, a questão de não pouca dificuldade é determinar se os elementos que reconhecemos como semelhantes a estratégias de escritores europeus tem o mesmo significado em Arguedas e no contexto andino. Uma resposta completa à pergunta teria que determinar se, além do conteúdo do livro, o próprio conceito de representação foi afetado, sendo inserido em outro paradigma. Não é outra a tese que vou defender aqui: a passagem de fato ocorre, graças à transformação do processo de produção de El zorro de arriba y el zorro de abajo em uma cerimônia semelhante à dança ritual descrita no conto "La agonía de Rasu-Ñiti" e em vários textos etnográficos de Arguedas.

Entre maio de 1968 e 2 de dezembro de 1969, dia de sua morte, a vida de Arguedas efetivamente mimetiza a dança agônica do dançarino Rasu-Ñiti. O livro começa anunciando, na primeira página do primeiro diário, uma morte que está por vir, como o fez o dansak' no início do conto, e em ambos aparecem os tradicionais sinais premonitórios. Rasu-Niti avisa que vai morrer e se despede das pessoas mais próximas, o que Arguedas fará através do diário e das cartas. Como Rasu-Ñiti ao se vestir para sua última dança, Arguedas, quando sente que está próximo à morte, começa a se preparar e também transforma a morte em um acontecimento coletivo e ritual, compartilhando-a com a comunidade de leitores. E se Rasu-Ñiti não se despede sem antes transmitir sua função social a um discípulo, Arguedas solicita em uma das últimas páginas que escreve que em seu enterro fale um aluno, Edmundo Murrugarra, cujas virtudes ele louva ${ }^{14}$.

Nas duas atividades - a dança e a escrita - o sujeito humano não é responsável por aquilo que produz. Enquanto no conto o dançarino está apenas obedecendo a uma divindade - a mãe diz à filha, sobre as tesouras utilizadas na dança, que "El Wamani las hace chocar. Tu padre sólo está obedeciendo" 15 - e a música, segundo o narrador, não "brotaba" das cordas e da madeira dos instrumentos, e sim de uma força extrahumana ${ }^{16}$, Arguedas descreverá sua escrita de forma parecida, chegando a utilizar o mesmo verbo:

cuando yo empiezo a escribir, empiezan a brotar mundos que yo mismo no sospechaba y uno no se convierte sino en una especie de médium, intermediario de verdaderos universos que van saliendo del cuerpo de uno de la manera más extraña ${ }^{17}$. 


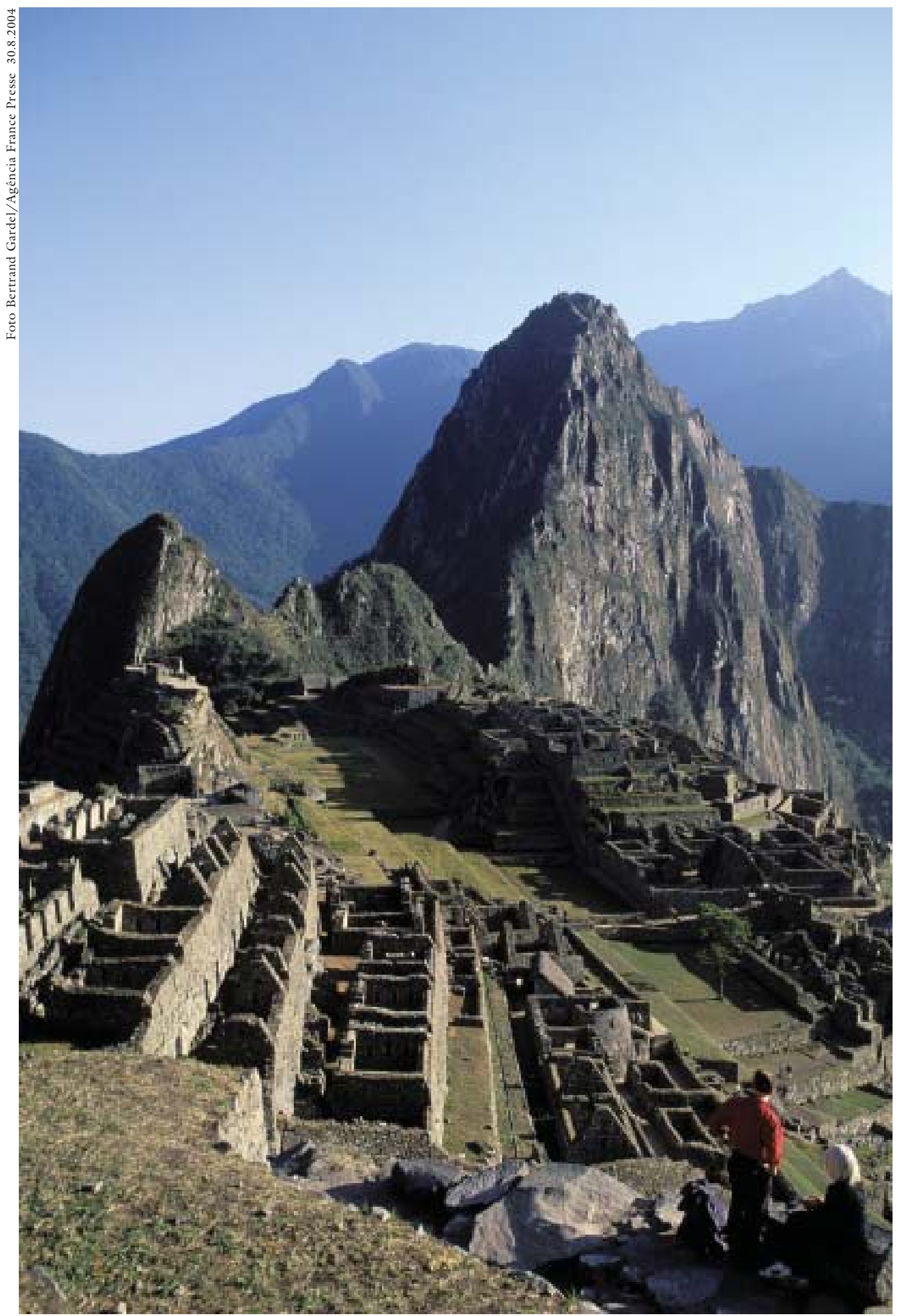

As ruínas incas de Machu Pichu estão a 2.500 metros acima do nível do mar nos Andes peruanos. 
Em ambos há, então, sinais de uma prática antimoderna e encantada de criação que esvazia o papel do sujeito criador $^{18}$.

O dilema, para um pensamento desde a esquerda, é o que fazer com esses momentos em que o subalterno rejeita sua própria agência, transferindo-a ao sobrenatural. Afinal, o subalterno, freqüentemente, não é o sujeito da história em seus próprios relatos, enquanto o objetivo de qualquer história progressista é justamente que ele o seja. Quando se descreve um acontecimento como a criação verbal como uma espécie de milagre - e portanto um evento cuja causa está fora da história ${ }^{19}$-, abre-se uma distância intransponível das explicações formuladas por teóricos e historiadores da literatura. Assim, em vez de transformar a religião em literatura e ficção, como se viu em tantas obras do período, neste caso é a literatura que é traduzida a outro contexto epistemológico e é, efetivamente, transformada em ritual. Se a transculturação literária celebrava a assimilação da tradição local pelo global, em Arguedas parece haver uma brecha para o movimento contrário: a assimilação da modernidade pela cultura local ${ }^{20}$.

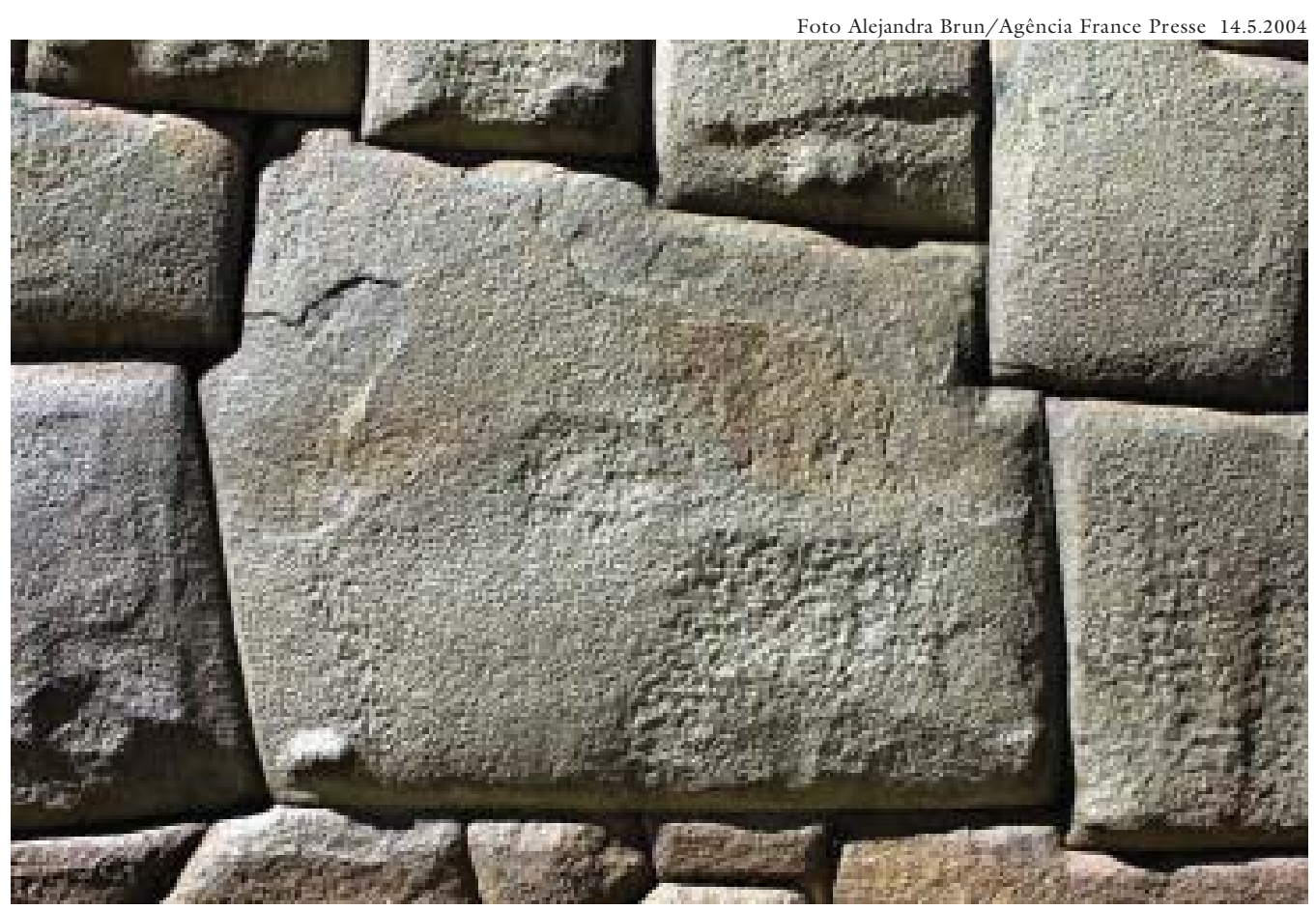

Pedra inca de "doze ângulos" no Palácio Hatunruniyoc, em Cuzco, no Peru.

Alberto Moreiras sustenta, em leitura recente, que o romance póstumo de Arguedas identifica o momento do óbito do realismo maravilhoso, com o esgotamento da capacidade crítica do modelo transculturador latino-americano. Para Moreiras, Arguedas leva o realismo maravilhoso a suas últimas conseqüências, até o ponto em que ele se desfaz, aniquilando a narrativa e o romance ${ }^{21}$. Seria possível afirmar ainda que com El zorro de arriba y el zorro de abajo o que ocorre 
é o questionamento do próprio conceito de literatura e, por extensão, da noção moderna de cultura. Com a problematização incorporada também ao processo de produção, como se viu, Arguedas termina negando a possibilidade de o encontro ser resolvido de forma satisfatória através da mescla ou da reprodução do local por meios modernos, já que percebera que a própria noção de cultura já era uma ameaça à visão de mundo que ele prezava ${ }^{22}$. Com esta constatação, desaparece a possibilidade da representação da diferença através da literatura, a razão de ser da transculturação narrativa.

A obra final de Arguedas desestabiliza de tal forma alguns elementos fundamentais para a definição moderna de literatura que o próprio conceito de ficção volta a ser estranho. Afinal, o conceito de literatura foi sempre o ponto cego nas discussões a respeito das possibilidades críticas da transculturação literária, embora se saiba que a definição do espaço literário a partir da noção de ficção essa relação oblíqua entre a representação e a realidade - é recente, cristalizandose na Europa só na época moderna. Nessa linha, embora não seja incomum considerar a literatura uma prática que esteve sempre livre das amarras das normas historiográficas e escapa de seu domínio, torna-se claro que a idéia de ficção uma representação verbal desvinculada da obrigação de objetividade - só funciona se existir seu avesso - uma representação discursiva objetiva, assim como só pode existir o fetiche - a illusio - se houver o seu contrário, o fato objetivo ${ }^{23}$. Com a categoria literatura, como com as de fetiche e ficção, cria-se um receptáculo para abrigar tudo aquilo que não é história.

A questão não se resolveria se disséssemos, como já fizeram alguns leitores de Arguedas, que seu texto final é na verdade uma autobiografia, pois a escolha da outra alternativa - isto é, dizer que se o texto não é ficção, é portanto nãoficção, historiografia, autobiografia, etnografia - mantém intato o dualismo que está na raiz do problema, com sua separação compulsória de fato e fetiche, objeto e sujeito, autobiografia e literatura. Não há autobiografia moderna em Arguedas porque não há um sujeito individual que se responsabilize pelo discurso e não há esse espaço onde, segundo Beatriz Sarlo, "la conciencia de sí pudo desarrollarse porque las relaciones seculares y privadas comenzaron a tener prioridad sobre la relación con Dios" 24 . A teoria da representação de Arguedas explica-se por uma concepção do sujeito em que essa consciência secularizada não predomina. Ao afirmar que "nada hay, para quien aprendió a hablar en quechua, que no sea parte de uno mismo" 25 , o autor demonstra que nela não são claros sequer os contornos do sujeito e sua separação do objeto, colocando em xeque a crítica antifetichista.

Fica claro, então, que o espaço reservado para os objetos verbais na modernidade - a ficção ou a história - é para Arguedas um canto fúnebre, com a agravante de que é uma derrota que se apresenta como algo a ser celebrado. Tornam-se problemáticas, assim, as histórias literárias latino-americanas totalizadoras que insistem na continuidade e na comensurabilidade. Se a cegueira em 


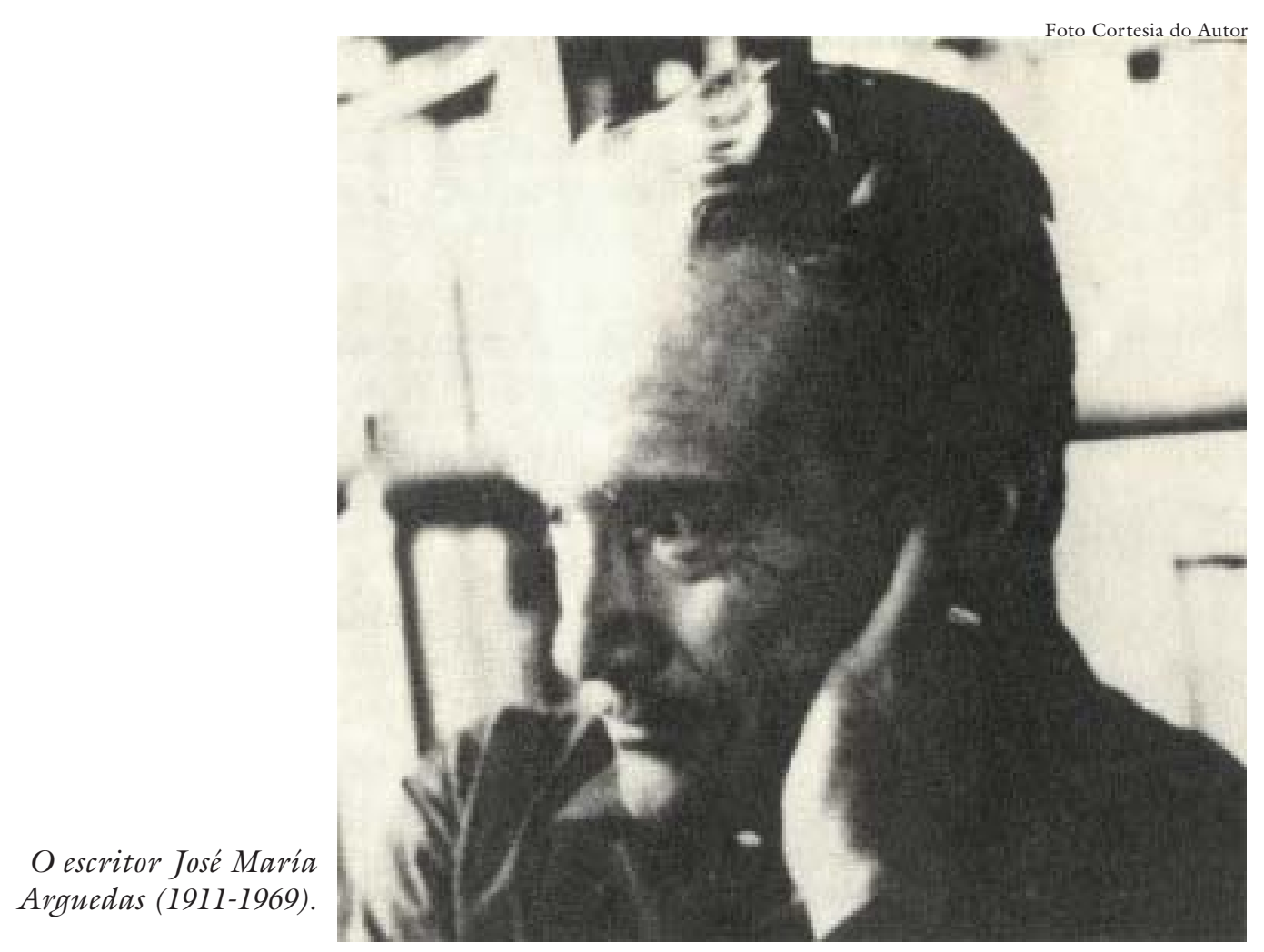

relação à especificidade do conceito de literatura é o que tornou possível a disciplina Literatura Comparada na América Latina, é aconselhável que o crítico que estuda práticas literárias limítrofes tenha também certo conhecimento da natureza de outras práticas discursivas. O crítico especializado em apenas uma das práticas discursivas vigentes no continente terá dificuldades em reconhecer as diferenças entre, por exemplo, uma narrativa secularizada e um relato encantado, pois esse crítico está no lugar de uma pessoa que, conhecendo intimamente apenas uma de duas línguas, não é capaz de enxergar os aspectos escandalosos da tradução entre elas ${ }^{26}$, neste caso a tradução necessária para que a religiosidade seja lida como ficção.

É esta percepção que torna Arguedas singular no campo dos escritores hispano-americanos do período. Se não faltam vozes dispostas a fazer a tradução de diferentes práticas discursivas a uma definição universalista de literatura, inclusive em nome dos subalternos, a voz solitária de Arguedas parece insistir no direito a não fazer literatura, no direito a não ser imediatamente reduzido à ficção, no direito a não ter que escolher entre fato e fetiche, literatura e história.

\section{Notas}

1 Ver, para o desenvolvimento deste argumento, Dipesh Chakrabarty, Provincializing Europe: Postcolonial Thought and Historical Difference, Princeton, Princeton University Press, 2000, pp. 72-77. 
2 Ángel Rama, “Os processos de transculturação na narrativa latino-americana”, em Flávio Aguiar e Sandra Guardini Vasconcelos (orgs.), Ángel Rama: Literatura e cultura na América Latina, trad. Rachel La Corte dos Santos e Elza Gasparotto, São Paulo, Edusp, 2001, pp. 213-214.

3 Idem, pp. 220-221. O otimismo de Rama não será tão grande em alguns textos posteriores, mas são formulações triunfalistas como essas que terão mais influência sobre a crítica hispano-americana.

4 Antonio Cornejo Polar, Martin Lienhard e Alberto Moreiras são algumas exceções.

5 "Nem racismos, nem xenofobias", em Jorge Schwartz, Vanguardas latino-americanas: Polêmicas, manifestos e textos críticos, São Paulo, Edusp/ Iluminuras/ Fapesp, 1995 , p. 595.

6 José María Arguedas, "La agonía de Rasu-Ñiti”, Relatos completos, Madrid, Editorial Losada, 1983, p. 220.

7 Rama, op. cit., p. 232.

8 Idem, p. 238.

9 Arguedas, "La agonía de Rasu-Ñiti”, pp. 213-214

10 José María Arguedas, "La novela y el problema de la expresión literaria en el Perú", em Abelardo Oquendo (org.), Un mundo de monstruos y de fuego, México, FCE, 1993, p. 212.

11 José María Arguedas, Los ríos profundos, México, Losada, 1998, p. 102. Para uma discussão do conflito lingüístico no romance, ver a dissertação Nas margens da palavra - o silêncio: uma estratégia de controle e organização do conflito em Arguedas de Ligia Karina Martins de Andrade, São Paulo, Universidade de São Paulo, 2004.

12 Miguel Ángel Asturias, Hombres de maiz, Gerald Martin (ed.), Madrid, ALLCA XX, 1996, p. 202.

13 Petra Iraides Cruz Leal em Dualidad cultural y creación mitica en José María Arguedas, Secretariado de Publicaciones, Universidad de la Laguna, s/e, s/d, pp. 192-193.

14 Devo esta última observação a Roberto Zular. Segundo Antonio Cornejo Polar, o leitor do livro seria também um herdeiro em potencial: "o romance pressupõe que o itinerário do narrador, que como novo zorro põe em contato os diversos mundos coexistentes em Chimbote, cuja função simbólica, relativamente ao Peru, é óbvia, será repetido pelos leitores". Em "Um ensaio sobre 'Los zorros' de Arguedas", O condor voa: literatura e cultura latino-americanas, trad. Ilka Valle de Carvalho, Belo Horizonte, Ed. UFMG, 2000, p. 151.

15 Arguedas, op. cit., p. 213.

16 Idem, p. 216.

17 Apud Alejandro Ortiz Rescaniere, "Los zorros devoradores", Revista de la Universidad Católica, Lima, n. 2, 31 dez. 1977, p. 86.

18 A morte individual tampouco parece ser decisiva, como explica o músico Lurucha no conto: "Dansak' no muere. Por dansak' el ojo de nadie llora" (Arguedas, op. cit., p. 220). É esta também a leitura de Cornejo Polar, tanto do conto - "A continuidade desembaraçada da dança subtrai à morte qualquer conteúdo trágico [...] e a converte em ritual prazeroso que assegura a renovada e infinita vitalidade dos homens instalados produtivamente nessa tradição" - quanto do romance - "Assim, para Arguedas a 
morte não é término e desaparecimento, nem expressão da fatal finitude humana; ao contrário, é instância de renovação e continuidade, de certa maneira vinculada ao ritmo da vida cósmica. Representa a definitiva abertura do ser pessoal para a multidão dos homens que continuam seu trabalho terreno. Por vezes, é, além disso, senha de redenção" (Cornejo Polar, “Um ensaio sobre 'Los zorros”, pp. 150-151).

19 O argumento exposto na primeira metade deste parágrafo está em Chakrabarty, Provincializing Europe, pp. 103-105.

$20 \mathrm{E}$ é por isso que pode não ser exagero afirmar que em El zorro de arriba y el zorro de abajo "a racionalidade opressora vem a ser contida, ou pelo menos tende a sê-lo, por uma forma de entendimento que não pode ser explicada dentro desses parâmetros" (Alberto Moreiras, A exaustão da diferença: A politica dos estudos culturais latinoamericanos, trad. Eliana Lourenço de Lima Reis e Gláucia Renate Gonçalves, Belo Horizonte, Ed. UFMG, 2001, p. 243), que "os componentes andinos são de tal magnitude e exercem tão decisivas funções que é legítimo pensar que nesse romance, pela primeira vez, a racionalidade indígena é portadora da modernidade" (Cornejo Polar, "Um ensaio sobre 'Los zorros", p. 148), que "Arguedas realiza finalmente un proyecto que ni Garcilaso de la Vega ni el propio Waman Poma tuvieron la posibilidad de defender consecuentemente: la reivindicación íntegra de los valores autóctonos" (Martin Lienhard, Cultura popular andina y forma novelesca: Zorros y danzantes em la última novela de Arguedas, México, Ediciones Taller Abierto, 1998, p. 41).

21 Moreiras, op. cit., pp. 230 e 237.

22 Em suas objeções a escritores contemporâneos como Carlos Fuentes e Alejo Carpentier, salta à vista a centralidade dada por Arguedas ao modo de produção da literatura. Em seu famoso debate com Cortázar é o estatuto do produtor o que mais uma vez está em jogo, com Arguedas se posicionando contra o escritor profissional, contra o distanciamento crítico, contra o antifetichismo como única possibilidade política. E contra o cosmopolitismo: "Todos somos provincianos, don Julio (Cortázar). Provinciano de las naciones y provincianos de lo supranacional que es, también, una esfera, un estrato bien cerrado, el del 'valor en sí', como usted con mucha felicidad señala" (em José María Arguedas, El zorro de arriba y el zorro de abajo, Madrid, Colección Archivos, 1992, p. 21).

23 Nas palavras de Bruno Latour, "Por trás da ostentação do antifetichismo, esconde-se uma teologia da criação". Em Reflexão sobre o culto moderno dos deuses fe (i)tiches, trad. Sandra Moreira, Bauru, Edusc, 2002, p. 103.

24 Beatriz Sarlo e Carlos Altamirano, "Del lector", em Literatura/Sociedad, Buenos Aires, Edicial, 1993, p. 125.

25 Apud Antonio Cornejo Polar, Los universos narrativos de José María Arguedas, Lima, Editorial Horizonte, 1997, p. 24.

26 Dipesh Chakrabarty, "The Time of History and the Times of Gods", em Lisa Lowe e David Lloyd (orgs.), The Politics of Culture in the Shadow of Capital, Durham, Duke University Press, 1997, p. 52.

RESUMO - VOLTAR ao escritor peruano José María Arguedas hoje, em meio a discussões sobre a especificidade histórica e conceitual da literatura, pode permitir que vejamos com outros olhos sua defesa de uma teoria da representação em que a dicotomia fato/ 
fetiche deixa de ter sentido. Se as narrativas transculturadoras da literatura hispanoamericana de meados do século XX se ocuparam da transformação da religião em literatura, o que se vê em Arguedas é, ao contrário, a tentativa de ritualização da literatura e a defesa de algo que poderíamos chamar, talvez, de um direito a não ser literatura.

PALAVRAS-CHAVE: Arguedas, Conceito de literatura, Literatura latino-americana.

ABSTRACT - A RETURn to Peruvian writer José Mar ía Arguedas today, amidst discussions regarding the historical and conceptual specificity of literature, may allow us to see in a new light his defense of a theory of representation in which the dichotomy fact/fetish loses its ground. If the narratives of transculturation in mid-twentieth-century Spanish American literature transformed religion into literature, in Arguedas what one sees is, on the contrary, the attempt to ritualize literature and defend something we could call, perhaps, a right to not be literature.

KEY-WORDS: Arguedas, Concept of literature, Latin American literature.

Marcos Piason Natali é professor do Departamento de Teoria Literária e Literatura Comparada da Faculdade de Filosofia, Letras e Ciências Humanas da Universidade de São Paulo. @ - mpnatali@hotmail.com

Recebido em 30.9.05 e aceito em 3.10.05. 